\title{
THE INTERPRETATION OF THE FILIOQUE CLAUSE BY ORTHODOX ECCLESIOLOGY AND BIBLICAL EXEGETICAL METHODOLOGY
}

\author{
Iakovos Menelaou \\ King's College, London ${ }^{1}$
}

\begin{abstract}
The filioque clause is one of the major differences between the Orthodox and Catholic Churches. The decision of the Catholic Church to add the filioque clause in the Creed not only caused many problems, but it still keeps the two Churches in distance. Although some attempts have been made to resolve the situation, the filioque remains an issue under dispute. While for Catholics it has the validity of Pope, according to Orthodox Ecclesiology and Biblical Exegetical Methodology, the filioque is a non-valid clause which disrupts the order of the Holy Trinity. In this paper, we are going to examine the filioque clause from an Orthodox perspective and explain why the Orthodox Church does not accept the term filioque as a valid addition in the Creed.
\end{abstract}

Key Words: Filioque; Orthodox Ecclesiology; Orthodox Biblical Exegetical Methodology; Augustine of Hippo

\section{Introduction}

Filioque, "and from the Son", alludes to the decision of the Catholic Church to add this clause in the Creed. Specifically, in the part of the Nicene Creed that refers to the procession of the Holy Spirit, the Latin Church preaches that the "Holy Spirit proceeds from the Father and the Son", as opposed to the pre-established view of the Orthodox Church (from the First and Second Ecumenical Councils in 325 and 381, respectively), that the Holy Spirit proceeds from the Father only. Since the fifth century when the filioque clause was firstly used in liturgy in Spain ${ }^{2}$ and 767 when Greeks possibly raised the issue at a formal level, ${ }^{3}$ it remains a Church dividing issue between Western and Eastern Churches. ${ }^{4}$ According to Cooper, the addition of the filioque clause by Latin-speaking Christians led to a serious showdown between East and West. The Westerns changed the wording, as they were dissatisfied with the language offered at the Council of Constantinople. ${ }^{5}$

Despite some efforts to face the disagreement through Ecumenical dialogue, the problem has not been resolved. In 1987 Patriarch Dimitrios I and in 1995 Patriarch Bartholomew visited Rome. On both occasions, Pope John Paul II and Patriarch proclaimed

\footnotetext{
Iakovos Menelaou is a PhD student at King's College, London.

Dietrich Ritschl, 'Historical Development and Implications of the Filioque Controversy', in Dikran Y

Hadidian (ed.), Intergerini Parietis Septum: Essays Presented to Markus Barth on his sixty-fifth Birthday

(Pennsylvania 1981), pp.288).

3 Tia M Kolbaba, The Byzantine Lists: Errors of the Latins (Illinois, 2000:40).

4 I am using the well-aimed title of the article 'The Filioque: a Church Dividing Issue? An agreed Statement of the North American Orthodox-Catholic Theological Consultation', Saint Paul's College, Washington, DC, October 25 2003, The Greek Orthodox Theological Review 49:3-4 (2004), pp. 359-92.

5 Derek Cooper, 'Are Jesus and the Holy Spirit Divine?'Twenty Questions that Shaped World Christian History (Augsburg, 2015), pp. 51-68.
} 
the Creed in Greek. After Bartholomew's visit to Rome, the Vatican composed a text intending to contribute to the dialogue between the two Churches. This is "The Greek and Latin Traditions Regarding the Procession of the Holy Spirit". ${ }^{\circ}$

\section{The Filioque Clause in History}

Although the Eastern Church kept the Nicene Creed without any changes, in the Latin West the case was different. The First Ecumenical Synod in Nicaea (325) and the Second Ecumenical Synod in Constantinople (381) composed and completed the Creed. ${ }^{7}$ According to these Ecumenical decisions, it should be unchanged; a position that the Eastern Church followed. However, in the West and first in Spain, the Council of Toledo in 589 added the filioque as a means against the Arian heresies. ${ }^{8}$ The Spanish bishops and King Reccared believed that there was indeed a Greek equivalent of the filioque, which was part of the original Creed. Their purpose was to oppose Arianism's position which doubts the divinity of Christ, by affirming the close relation between the Father and the Son. ${ }^{9}$ In that way, they wanted to show that the Son is not inferior to the Father (against Arianism) and also that the Spirit consists of the same substance as the Father and the Son (against Priscillianism). ${ }^{10}$

The origins of the filioque could be found in Augustine of Hippo (359-431), whose philosophical model was spread and adopted by the West in Middle Ages, constituting a profession of faith. ${ }^{11}$ According to him, Scripture preaches a double procession, since it refers to the Spirit of both, the Father and the Son; also essential element of his teaching is the idea of one Godhead which is Trinity. ${ }^{12}$

In the second half of the eight century and after a series of letters' exchange with the Pope Hadrian I, Charlmagne (768-814), son and successor of Pippin, ordered the writing of the Libri Carolini. ${ }^{13}$ Charlmagne mainly wanted to revive the West Roman Empire, ${ }^{14}$ but he also evoked tensions with the Byzantine Empire. Apart from the fact that his theologians, who were commissioned to compose the Libri Carolini, attempted to raise the great issue of Iconoclasm (which kept iconodules and iconoclasts Byzantines in battle for more than a century), ${ }^{15}$ the Libri Carolini declared the validity of the filioque clause. According to Charlmagne's theologians "it is rightly and customarily believed that the Holy Spirit proceeds from the Father and the Son". ${ }^{16}$

The next two councils encouraged the use of the filioque in the Creed, in order to confront 'Adoptionism', a heresy which rose in Spain. In the presence of Charlmagne, the Council of Frankfurt (794) approved the filioque, while Paulinus of Aquileia (+802) in the

The Filioque: a Church Dividing Issue? p. 379.

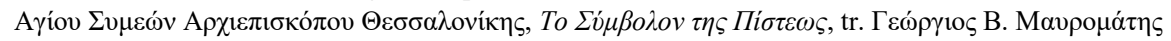
(Katerini, 1997), p. 16.

8 Despina Stratoudaki White, Patriarch Photios of Constantinople: his life, scholarly contributions, and the correspondence together with a translation of fifty-two of his letters (Massachusetts, 1981), pp. 32.

9 The Filioque: a Church Dividing Issue? p. 365.

10 Mark E Chapman, A Lutheran Proposal for the Neuralgic Question of the Filioque: the LWF at Curitiba, Brazil, 1990, Journal of Ecumenical Studies 28:2 (1991), p. 242.

11 Saint Photios Patriarch of Constantinople, On the Mystagogy of the Holy Spirit, tr. Holy Transfiguration Monastery (Studion Publishers, 1983), p. 10.

12 Robert M. Haddad, 'The Stations of the filioque', St Vladimir's Theological Quarterly 46:2 (2002), p. 213.

13 The Filioque: a Church Dividing Issue? p. 368.

14 Saint Photios, On the Mystagogy of the Holy Spirit, p. 12.

15 The Filioque: a Church Dividing Issue? p. 367.

16 Haddad, 'The Stations of the filioque', p. 221. 
Council of Friuli (796) defended its use in teaching and in the celebration of the Eucharist. $^{17}$

Charlmagne's persistence in the prevailing of the filioque led him to another decisive step: the composition of De Spiritu Sancto in 809. Charlmagne commissioned Theodulf of Orleans, who was the main author of the Libri Carolini, to write a defense of the filioque. As a result, his De Spiritu Sancto which consisted of patristic mentions supported the filioque clause. De Spiritu Sancto could be seen as a response to the conflict between Western and Eastern monks at Saint Sabas monastery in Jerusalem. ${ }^{18}$ The Western monks used the Latin version of the Creed, provoking the reaction of the Eastern monks. ${ }^{19}$ In addition, in the same year Charlmagne convened the Council of Aachen, pursuing to establish the filioque. ${ }^{20}$ Although the Pope, Leo III, approved its use in catechesis, he assured the Orthodox Church that it would not be included in the Creed. However, Charlemagne ignored Leo's suggestions and spread the filioque clause in the West, in countries like France, Spain, Germany and northern Italy. ${ }^{21}$

It was not earlier than the ninth century, when the East appears to be really interested in the filioque issue. In the middle of that century Western delegates attempted to impose the Latin version of the Creed in Bulgaria; and moreover, King Boris, under Western influence, was reluctant to accept Byzantine missionaries in his country. ${ }^{22}$ Then, Patriarch Photios of Constantinople (from 858-867 and from 877 to 886 ) $^{23}$ played a key role in the whole issue. In his "On the Mystagogy of the Holy Spirit", ${ }^{24}$ and also in his encyclical letter to all Eastern Patriarchs in 867, Photios condemned the inclusion of the filioque in the Creed and characterised it as heretical. ${ }^{25}$ The council that took place in Constantinople in 867 denounced Pope Nicholas I, as response to the latter's decision not to recognise Photios as the new Patriarch. The Council of Constantinople in 867 could be seen as the beginning of the so-called Photian Schism. ${ }^{26}$

During his second period as Patriarch (when he succeeded Ignatius after his death in 877), Photios continued his leading role in the filioque issue. The Council of Constantinople in 879-880, in the presence of Western and Eastern delegates confirmed the original Creed of 381, without the filioque clause, while at the same time it condemned anyone who would propose any changes. ${ }^{27}$

In the eleventh century, the distance between the two Churches became more obvious. In 1004, Pope Sergius IV included the filioque in his statement of faith addressed to Constantinople, ${ }^{28}$ while during the coronation of King Henry II of Rome the Latin version of the Creed (including the filioque) was sung as part of the Roman mass in the presence of

\footnotetext{
The Filioque: A Church Dividing Issue? pp. 368-369.

Ritschl, 'Historical Development and Implications of the Filioque Controversy', p. 288.

The Filioque: a Church Dividing Issue? p. 369.

Ibid., p. 369.

Haddad, 'The Stations of the Filioque', p. 226.

The Filioque: A Church Dividing Issue? p. 370.

White, Patriarch Photios of Constantinople, p. 15.

His work 'On the Mystagogy of the Holy Spirit' which deals in depth with the filioque will be discussed on the next pages.

25 Haddad, 'The Stations of the filioque', p. 229.

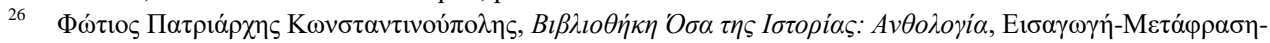

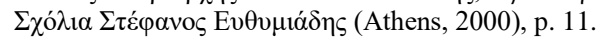

27 The Filioque: a Church Dividing Issue? p. 372.

28 Ritschl, 'Historical Development and Implications of the Filioque Controversy', p. 290.
} 
Pope Benedict VIII. ${ }^{29}$ Finally in 1043, Leo IX added officially the filioque in the Creed; a decision which was considered an abuse by the East. ${ }^{30}$ The estrangement between the two parts, East and West, was a fact. In 1054, the year of the Schism between the two Churches, we had a series of excommunications, mainly, because of the filioque. Leo IX from the West and Patriarch Michael from the East were central personalities of the period. ${ }^{31}$

Even if one could say that the events of the first half of the eleventh century did not cause a formal Schism, the actions of the Fourth Crusade and the sack of Constantinople by the Crusaders in 1204 made clear that the rift was more obvious than ever. After his election, Peter the Innocent had a basic aim: to free and reclaim the Holy city (Jerusalem) from the Muslims. ${ }^{32}$ However, the Crusaders' plans swerved and they turned against the Byzantines, as they had been seen as schismatic by the Westerns. ${ }^{33}$ The assault on Constantinople was seen as an attack "for the honour of the Holy Roman Church and for the relief of the Holy Land". ${ }^{34}$

In fact, the filioque should be seen as a fundamental difference between the Catholic and Orthodox Churches, which divides them for centuries. Although it is not the only reason for the distance between the two Churches, it has caused a sharp rift in their relations. Nonetheless, we should not ignore some attempts to face the problem. For instance, the Council of Lyon in 1274 attempted a re-union; ${ }^{35}$ in the later Council of Blachernae in 1285, the East rejected the manifestation of the double procession of the Holy Spirit and spoke of an 'eternal manifestation' through the Son; in the Council of Ferrara-Florence (1438-1445), the filioque was presented by both sides as the same with the phrase through the Son ${ }^{36}$ a former East position expressed by Athanasius ${ }^{37}$ and developed further by Gregory Palamas, after the Council of Blachernae. ${ }^{38}$ More recently, the Second Vatican Council (1962-1965) and the Pan-Orthodox Conferences (1961-1968) made also some effort to face the filioque issue effectively. ${ }^{39}$

\section{The Background of Orthodox Ecclesiology; Photios' Mystagogy}

The Trinity is a vital element of Orthodox ecclesiology. Since the filioque suggests changes in the Creed (disrupting the structure of the Holy Trinity), then Orthodox ecclesiology is under dispute. According to Dragas, the Trinity provides Orthodox ecclesiology with the basic ontological categories and the Church is an eikon of the Holy Trinity. ${ }^{40}$

It is very important to understand the idea of primacy in Catholic theology and the way this primacy is rejected by Orthodoxy. In Orthodox ecclesiology, all bishops are equal and all churches too. There is no difference between the bishop of any small place and the Ecumenical Patriarch of Constantinople, although Metropolitans, Archbishops and

The Filioque: a Church Dividing Issue? p. 372.

Saint Photios, On the Mystagogy of the Holy Spirit, p. 27.

The Filioque: a Church Dividing Issue? p. 373.

Jonathan Phillips, The Fourth Crusade and the Sack of Constantinople (Pimlico, 2005), p. 5.

Ibid., p. 160.

Ibid., p. 175.

Ritschl, 'Historical Development and Implications of the Filioque Controversy', p. 290.

The Filioque: a Church Dividing Issue? pp. 375-76.

Ritschl, 'Historical Development and Implications of the Filioque Controversy', p. 295.

The Filioque: a Church Dividing Issue? pp. 375-76.

Ibid., pp. 377-78.

George Dragas, 'Orthodox Ecclesiology in Outline', The Greek Orthodox Theological Review 26-3 (1981), pp. 185-86. 
Patriarchs have some increased responsibilities. Equality is the main characteristic, since their authority is limited by their role as bishops. This is not to suggest that there are many bodies of Christ, as there is only one Eucharistic body. It is the one Christ who gives His body to all people in many places; and this is the substance for what we call 'Orthodox Eucharistic ecclesiology'. This communion in the one body of Christ constitutes the ecclesiastical ontology.

On the other hand, this kind of equality is absent from the Catholic Church, in which all local churches constitute the Body of Christ. This is the Universal ecclesiology, whose main characteristic is the fact that it consists of parts and whole. ${ }^{42}$ Consequently, the existence of local churches is not verified by the communion in the one grace of Christ and the Trinity, but by accepting the Church of Rome as the one local Church and the Pope of Rome as the head of this Church, superior to any other bishop. ${ }^{43}$

Inevitably, there is a substantial difference in the way that the two Churches perceive the idea of primacy. On the first hand, the Orthodox Church does not have any real distinction between its members, since they are all equal. As Dragas says, She does not seek Her own glory, but that of the Lord and His Saints. ${ }^{44}$ In contrast, the Catholic Church sees Pope and his primacy as a necessity. He is the supreme power. ${ }^{45}$

The filioque became a real problem when the Latins unilaterally made of their theological formulation a dogmatic confessional formula and changed the original common text of the Creed. ${ }^{46}$ In addition, at a certain point, the difference in the ecclesiology of the two Churches explains the disagreement on the filioque issue. It is common knowledge, indeed, that this addition was a unilateral one; a decision made by the Western Church. According to them, the filioque is a valid change, as it was imposed by the Pope who is the Head of the Catholic Church. In contrast, Orthodox ecclesiology, without accepting the authority and primacy of Pope, cannot see the filioque as a valid addition. Besides, the Orthodox Church persists in the decisions of the Synods which composed and completed the Creed and condemned anyone who would change it. ${ }^{47}$ In general, the Synod has an exceptional importance and supreme authority in Orthodoxy; it is here, where all Churches acknowledge their ontological unity as the One, Holy, Catholic and Apostolic Church. ${ }^{48}$ As a result, the addition of the filioque to the original Creed is non-canonical, since it does not have the validity of an Ecumenical Council. ${ }^{49}$

Photios was the first to present the filioque as a significant theological issue and not only as an insertion in the Creed. ${ }^{50}$ His Mystagogy, a book dealing exclusively with this issue, rejects the filioque as heretical. Photios attempts to demonstrate that Latins' suggestion constitutes threat for the Trinity. By defending the original Creed and the Trinity, Photios also defends Orthodox ecclesiology. In his Letter to the Patriarch of

\footnotetext{
41 Dragas, 'Orthodox Ecclesiology in Outline', pp. 186-87.

42 Alexander Schmemann, The Idea of Primacy in Orthodox Ecclesiology, The Primacy of Peter, John Meyendorff (ed.), Crestwood, NY: SVS Press, pp. 150-51.

43 Dragas, 'Orthodox Ecclesiology in Outline', pp. 187-88.

44 Ibid., p. 192.

45 Schmemann, The Idea of Primacy in Orthodox Ecclesiology, p. 151.

46 Edward G Farrugia, 'The Eucharistic Liturgy and the Synod of Diamper', Gregorianum, Vol. 92, No. 3 (2011), pp. 617-621.

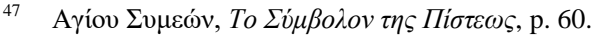

48 Schmemann, The Idea of Primacy in Orthodox Ecclesiology, pp. 158-59.

49 Ritschl, 'Historical Development and Implications of the Filioque Controversy', p. 286.

50 Warren Treadgold, 'Inventing Latin Heretics: Byzantines and the Filioque in the Ninth Century by Tia Kolbaba', The American Historical Review, Vol. 116, No. 3 (2011), pp. 855-856.
} 
Aquileia and his Mystagogy, Photios mentions that his motives were both biblical and theological. They were biblical, because they were based on the preaching of Saint John's Gospel: "the Spirit proceeds from the Father"; and theological, because the filioque clause suggests two origins in the Trinity, and at the same time it destroys the monarchy of the Father. $^{51}$

Obviously, Photios not only rejects the addition of the filioque, but he considers it deception and false teaching. ${ }^{52}$ The main component of his doctrine is that the Spirit proceeds from the Father only. ${ }^{53}$ The filioque turns against the fundamental Orthodox teaching that the Father is the only origin of the Trinity, since it suggests a joint procession of the Spirit; from the Father and the Son. ${ }^{54}$ As Photios attempts to show, the filioque damages the order of the Trinity and also opposes the preaching of the Bible, the Ecumenical Councils and the teachings of the Fathers. ${ }^{55}$ Bearing also in mind the fact that the Pope took authority by his own imposing the filioque, Photios concludes that the addition of the filioque is a blasphemy and betrayal. It has no position in the tradition of the Church and it is a will of the devil. ${ }^{56}$

Also, in his filioque polemics, Nicephorus Blemmydes reopened discussion on the notions of 'Son', 'Spirit' and 'Father'. He recalled the definitions of hypostasis through the notion of energy, instead of the notion of essence. The resulted definitions of hypostasis were more useful for further discussion of the two hypostases' proceedings. Thus, Blemmydes suggested a compromise understanding of the filioque. Also, Gregory Palamas claimed that the filioque implies an order within the divine nature, but there is no order between the three hypostases. ${ }^{57}$

The consultations which took place at Schloss Klingenthal in France, in 1978-79, ${ }^{58}$ was an attempt to look at the problem satisfying both sides. The Klingenthal Memorandum affirms the positive content of the filioque as an attempt to express the biblical teaching, that the Spirit is also the Spirit of the Son (in accordance with the Western Church); but in addition, it maintains that the Spirit proceeds from the Father alone, affirming His uniqueness (in accordance with the Eastern Church). ${ }^{59}$ Thus, the Memorandum offers a list of proposals as follows: the Spirit proceeds from the Father of the Son; the Spirit proceeds from the Father through the Son; the Spirit proceeds from the Father and receives from the Son; the Spirit proceeds from the Father and rests on the Son; the Spirit proceeds from the Father and shines out through the Son. ${ }^{60}$ Although such proposals could be accepted by

51 Fr. George Dion. Dragas, 'The Eight Ecumenical Council: Constantinople IV (879/880) and the Condemnation of the Filioque Addition and Doctrine, The Greek Theological Review 44/1-4 (1999), p. 360. Bradley Nassif in his review of the Edward Siecienski's book The Filioque: History of a Doctrinal Controversy (Oxford, 2010) also notes that Sicienski in his book sees John 15:26 as a key text on the filioque. This exegetical approach is important, as so much historical theology is done apart from its scriptural moorings (Church History, Vol. 80, No 3/2011, pp. 668-670). Saint Photios, On the Mystagogy of the Holy Spirit, p. 22.

3 Ritschl, 'Historical Development and Implications of the Filioque Controversy', p. 291.

54 Theodore Stylianopoulos, An Ecumenical Solution to the Filioque Question, Journal of Ecumenical Studies 28.2 (1991), p. 267.

55 Saint Photios, On the Mystagogy of the Holy Spirit, p. 26.

$56 \quad$ Ibid., p. 27.

57 Basil Lourié, 'Nicephorus Blemmydes on the Holy trinity and the Paraconsistent Notion of Numbers: A logical Analysis of a Byzantine Approach to the Filioque', Studia Humana, Volume 5:1 (2016), pp. 40-54. Theodore Stylianopoulos, The Filioque: Dogma, Theologoumenon or Error?, The Greek Orthodox Theological Review 31.3/4 (1986), p. 255. 
Orthodox theologians, there are still serious objections which are connected to the origins of the filioque and the doctrine of Augustine, that the Son is a source of the Spirit too. ${ }^{61}$

\section{Orthodox Biblical Exegetical Methodology}

The filioque originates from Augustine who teaches the Son's active participation in his own sending. ${ }^{62}$ Augustine preaches the "one essence of God which in itself is triune". Thus, the Father begets the Son and the Spirit is the mutual love, common to Father and Son (filioque). ${ }^{63}$

Augustine progressed from Manichaeism and Neoplatonism to Christianity, and apparently his teaching originates from a philosophical background and more specifically Plato. ${ }^{64}$ In Plato's view, the reality of things appears in his so-called immaterial universals; and God is to be understood as the universal above all particular universals. In addition, Plato's God has no choice but to use the pre-existing eternal ideas or universals. ${ }^{65}$ Therefore, the God of Plato and later of Neoplatonism is not the same as the biblical God, who creates the world ex nihilo because of love for people. ${ }^{66}$

Neoplatonism was developed by the philosophers Plotinus and Porphyry. According to this view, the One God necessarily creates two finite particulars, which lead to all the others: he produces the Nous, which together with the One creates the World-soul. Will and activity are identified with the essence and therefore these acts of creation are acts of the essence. In that way, creation seems to emanate from the divine essence ad infinitum. Without any real distinction between essence and energies or between theology and economy all things are gods in themselves, since they could be seen as pieces of the divine essence. Augustine's theology follows such a Neoplatonic model. In his view the divine essence corresponds to the Neoplatonic One and is defined as being 'simple'. ${ }^{67}$

As a result, Augustine's view with such a philosophical background has no position in Orthodox theology, whose main tool for the interpretation of Bible is tradition. In Augustine's theory the philosophical surmise to think the Trinity not by beginning, but with just the Trinity is important. Augustine teaches the Son's participation in his own sending. The three persons of the Trinity share these qualities which together become one principle. Inevitably, Augustine preaches the filioque. ${ }^{68}$

From an Orthodox perspective, the starting point for the interpretation of the Bible appears in the affirmation of 2 Timothy 3:26 that "all Scripture is inspired by God." This involves a synergy (cooperation) between the Holy Spirit of God and the human instrument who is the recipient and translator of divine revelation into gospel preaching. ${ }^{69}$ Tradition provides Orthodoxy with the hermeneutic perspective of biblical interpretation, since this is the certain way of interpretation. The Bible is not 'self-interpreting'. In contrast, it can only

\footnotetext{
Ibid., p. 267-8.
}

Ritschl, 'Historical Development and Implications of the Filioque Controversy', p. 300.

63 Chapman, A Lutheran Proposal for the Neuralgic Question of the Filioque: the L.W.F. at Curitiba, Brazil, 1990, p. 243.

64 Philip Zymaris, Neoplatonism, the filioque and Photios' Mystagogy, The Greek Orthodox Theological Review 46:3-4 (2001), p. 345.

65 Ibid., pp. 346-47.

66 Ibid., p. 347.

67 Ibid., p. 348.

68 Ritschl, 'Historical Development and Implications of the Filioque Controversy', p. 300.

69 John Breck, Scripture in Tradition: the Bible and its Interpretation in the Orthodox Church (New York, 2001), p. 9. 
be interpreted in the light of Holy Tradition, which gives the original content of Scripture. In addition, we should draw attention to the fact that Scripture as written text is born of Tradition. Cosequently, any biblical text could only be properly interpreted through focus on Tradition. $^{70}$

The Word of God is significant in every aspect of Orthodox life. This is how we could explain the fact that doctrines and teachings originate from the canonical writings. Psalms, historical events, prophecies, Epistles and Gospels are read continually, as a prominent element of Orthodoxy. The only exception is the Book of Revelation because of its undistinguishable and apocalyptic content. Besides, the Bible works iconically in liturgy and has central role in the personal life of each faithful person: iconically in liturgy, because the four Gospels are always on the altar of Orthodox churches as depictions of Christ's crucifixion and resurrection; and also, in daily life of each faithful, because the Bible provides him or her with admonition. ${ }^{71}$

From an Orthodox point of view, the role of the Bible seems to be minimal in the Catholic Church. As opposed to the Orthodox approach which could be characterised as holistic and synthetic, the Catholic approach is more 'scientific' and 'objective'. ${ }^{2}$ A Catholic approach is reminiscent of modern literary theories and specifically structuralism, since the West recruited methods from 'new literary criticism' in order to approach biblical studies and give them an in depth analysis. ${ }^{73}$

In that way, the interest is focused on the reader and how he reads the text. Although this could be useful applied to modern literature and at some extent to biblical studies, from an Orthodox perspective this method presents a great disadvantage: this is the characteristic of relativism, with the subsequent harm in the authority of biblical witness. Such approach sees as authentic only the events of Jesus' earthly life and prior to his crucifixion. This view opposes the Orthodox one, in which Jesus continues to speak after his crucifixion through the voice of the Holy Spirit. And here, the role of Tradition is confirmed, since it is not just a total of memories and archives, but even more a living reality that shows the right way of interpretation nourishing faithful people. ${ }^{74}$

According to the Orthodox Church, the Latin Church misunderstood the writings and teachings of spiritual Fathers and ignored the theology since the era of our apostles; the Western Church became reason of differences and disagreement. ${ }^{75}$ The filioque addition provoked the following negative results: by introducing a double procession of the Spirit, it confuses the uniqueness of the Father; it destroys the monarchy of the Father and eliminates the hierarchy of the Trinity; and finally, it ignores the distinction between person and nature, since generation and procession are likely only as acts of love grounded in personal freedom. Thus, the begetting of the Son and the bringing forth of the Spirit can only be actions of the Father as person. ${ }^{76}$

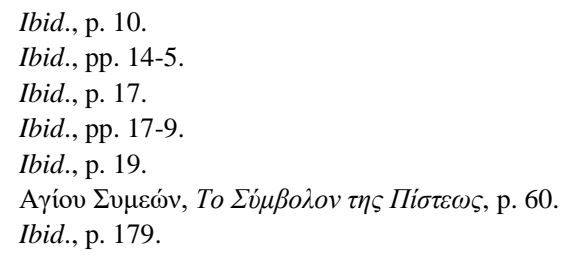




\section{Conclusions}

As Ritschl writes the development of the filioque controversy is firmly associated with political interests and conflicts. However, we should not conclude that the problem is in its nature a political one. ${ }^{77}$ Indeed, we could say that at some point the whole issue has a political aspect. For instance, Charlmagne's attempt to revive the Roman Empire could be seen as relevant with his personal and political aspirations. But the roots of the controversy are in the different Trinitarian concepts of each Church and the different way in which they approach the Bible. In fact, the filioque is a disagreement on the different ways that the Catholic and Orthodox Churches explain dogma. It is not a difference in dogma, but in the interpretation of dogma. $^{78}$

Catholics defend the double procession of the Spirit as an effort to clarify the unity of the divine action in the Creed, as opposed to Orthodox Christians who declare that this defence teaches the equality of the persons in the Trinity. However, both sides should reevaluate their views, bearing in mind the fact that the Creed does not arise from theological issues on their own right, but from confessional assertions in regard to the source of Christian identity. ${ }^{79}$ On the one hand, the Catholic Church should admit that the filioque is, after all, an addition which is not accompanied and confirmed by the value of an Ecumenical Council, even if its content is positive. On the other hand, the Orthodox Church should admit that despite the addition of the filioque without an Ecumenical council, it is indeed legitimate and valuable, since it emphasises the unity of the Trinity and the close relationship between the Son and the Spirit. ${ }^{80}$ Concluding, the different way the two Churches interpret dogma and explain the filioque is the greatest obstacle to settle on a final statement that would satisfy both sides.

\section{BIBLIOGRAPHY}

Breck, J 2001. The Bible and its Interpretation in the Orthodox Church. New York.

Chapman, ME 1991. "A Lutheran Proposal for the Neuralgic Question of the Filioque: The

LWF at Curitiba, Brazil, 1990.” Journal of Ecumenical Studies 28:2, pp. 239-59.

Cooper, D 2015. “Are Jesus and the Holy Spirit Divine?” Twenty Questions that shaped

World Christian History. Augsburg, pp. 51-68.

Dragas, G 1981. “Orthodox Ecclesiology in Outline.” The Greek Orthodox Theological

Review 26:3, pp. 185-92.

Dragas, Fr. GD 1999. “The Eight Ecumenical Council: Constantinople IV (879/880) and the Condemnation of the Filioque Addition and Doctrine." The Greek Orthodox

Theological Review 44:1-4, pp. 357-69.

Farrugia, EG 2011. "The Eucharistic Liturgy and the Synod of Diamper." Gregorianum, Vol. 92, No. 3, pp. 617-621.

Haddad, RM 2002. "The Stations of the Filioque.” St. Vladimir's Thological Quarterly 46:2, pp. 209-68.

Kolbaba, TM 2000. The Byzantine Lists. Illinois.

\footnotetext{
77 Ritschl, 'Historical Development and Implications of the Filioque Controversy', p. 300.

78 Stylianopoulos, The Filioque: Dogma, Theologoumenon or Error?, p. 279.

79 Lloyd G Patterson, 'The Spirit, The Creed, and Christian Unity, The Greek Orthodox Theological review 31:3-4 (1986), p. 246.

80 Stylianopoulos, An Ecumenical Solution to the Filioque Question?, p. 276.
} 
Lourié, B 2016. "Nicephorus Blemmydes on the Holy trinity and the Paraconsistent Notion of Numbers: A logical Analysis of a Byzantine Approach to the Filioque." Studia Humana, Volume 5:1, pp. 40-54.

Patterson, LG 1986. "The Spirit, the Creed, and Christian Unity." The Greek Orthodox Theological Review 31:3-4, pp. 235-54.

Phillips, J 2005. The Fourth Crusade and the Sack of Constantinople. Pimlico.

Nassif, B 2011. The Filioque: History of a Doctrinal Controversy by Edward Siecienski, Church History, Vol. 80, No 3, pp. 668-670.

Ritschl, D 1981. "Historical Development and Implications of the Filioque Controversy", in DY Hadidian (ed.), Intergerini Parietis Septum: Essays Presented to Markus Bath on his Sixty-fifth Birthday. Pennsylvania.

Stratoudaki-White, D 1981. Patriarch Photios of Constantinople: His Life, Scholarly Contributions, and Correspondence together with a Translation of Fifty-two of his Letters. Massachusetts.

Saint Photios 1983. On the Mystagogy of the Holy Spirit. Studion Publishers.

Stylianopoulos, T 1986. "The Filioque: Theologoumenon or Error?” The Greek Orthodox Theological Review 31:3-4, pp. 255-88.

Stylianopoulos, T 1991. “An Ecumenical Solution to the Filioque Question?' Journal of Ecumenical Studies 28:2, pp. 260-80.

Schmemann, A 1992. "The Idea of Primacy in Orthodox Ecclesiology", in J Meyendorff (ed.), The Primacy of Peter. Crestwood, NY:SVS Press.

Siecienski E 2010. The Filioque: History of a Doctrinal Controversy. Oxford.

Statement of the North American Orthodox-Catholic Theological Consultation, Saint Paul's College 2004. "The Filioque a Church Dividing Issue? An Agreed Statement of the North American Orthodox-Catholic Theological Consultation, Saint Paul's College, Washington, DC, October 25, 2003." The Greek Orthodox Theological Review 49:3-9, pp. 359-92.

Treadgold, W 2011. "Inventing Latin Heretics: Byzantines and the Filioque in the Ninth Century by Tia Kolbaba." The American Historical Review, Vol. 116, No. 3, pp. 855-856.

Zymaris, P 2001. "Neoplatonism, the Filioque and Photios' Mystagogy." The Greek Orthodox Theological Review, 46:3-4, pp. 345-62.

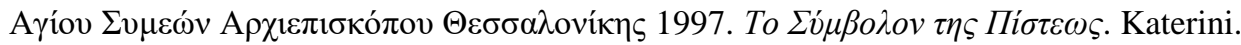

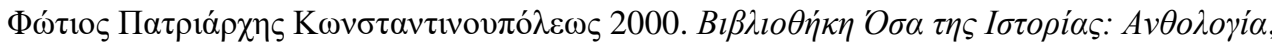

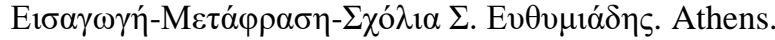

